\title{
Study regarding the physical-mechanical properties of knits for garments - pilling performance
}

\author{
Alina Mihaela Coldea ${ }^{1, *}$, and Dorin Vlad ${ }^{1}$ \\ ${ }^{1}$ Lucian Blaga University of Sibiu, Department of Industrial Machinery and Equipment, 10 Victoriei \\ Bd., 550024 Sibiu, Romania
}

\begin{abstract}
The effect of the pilling degradation results is an important decreasing in garment quality and a negative influence on the user's comfort to wear. There are a lot factors, such as the yarn spinning system, fabric geometry and finishing operation, which affect the pilling performance. This research paper presents the investigation of fabric surface concerning pilling formation, especially knits, influenced by the fibrous composition. As samples were used knitted fabric panels, obtained from carded yarns, with fibers composition like cotton, wool or mixed one. Regarding fabric geometry 3 types were used - single jersey, $2 \times 2$ rib and moss stitch. In order to establish which of the yarns are most appropriate for knitting garments from the point of view of pilling resistance were realized tests using the standard SR EN ISO 12945-2.The tests were performed with the Nu-Martindale - Abrasion and Pilling Tester, Model 864.For assessment were used two methods - the first one is a comparison with visual standards, tested fabrics or photographs of fabrics, to find the degree of pilling on a scale from 5 (no pilling) to 1 (very severe pilling) and the second one by determination of mass loss percent.
\end{abstract}

\section{Introduction}

The process of pilling appearance consists of three steps [1-2]: because of mechanical impact to the surface of garment, several fibers tips are pulled out creating a peeled surface (figure 1). Then the broken fibers come to separate tips and forms, gradually increasing pills.

The fibers that retain these balls are still subjected to mechanical stresses, due to other factors (wear, washing, etc.), resulting in the friction wear effect that leads to their fall. [34].

The resistance to pilling of the fabric depends on the fabric density, i.e. when the length of loop structure decrease and the surface density increases, the pilling resistance grows [57]. The correct form of yarn, fabric and fabric formation can improve the quality of knit fabric [8-9]. Washing intensity, cleaning process [10] that varies depending on chemical softeners used during washing [11-12], however, their influence is not fully investigated.

* Corresponding author: $\underline{\text { dorin.vlad@ulbsibiu.ro }}$ 


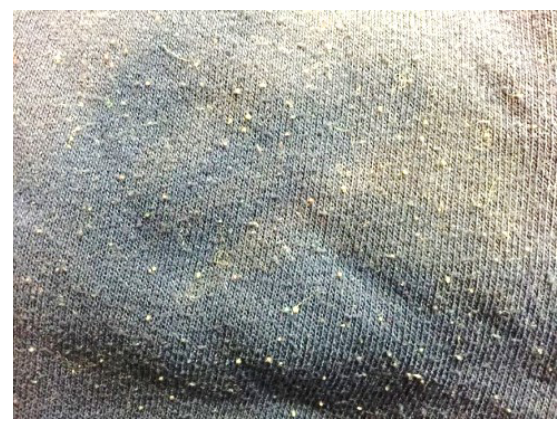

Fig. 1. Pilling effect appearance.

\section{Background}

There are many factors, like the yarn spinning mode, fabric geometry and finishing operations, which affect pilling performance [9, 15]. Özdil et all compared knitted fabrics from compact spun yarns with classic ring spun yarns and find that knitted fabric from compact yarns have better pilling performance [16]. Candan \& Önal test the pilling effect of weft knitted fabric made of OE and RS yarns. They say that $100 \%$ cotton samples knitted from RS yarns goes to have lower pilling rates than those made from $100 \%$ cotton OE spun yarns [17]. Beltran et al. [18] compared piling effect between fabrics made from conventional worsted spun yarns, solospun ring spun yarn and jetwind modified yarns, and report that compared to conventional ring spun yarn fabric, the pilling performance of solospun yarn fabric and jetwind modified yarn fabric showed a half grade and full grade improvement.

As well as an expensive textile fabric, cashmere fiber exhibits a tiny diameter, short length and very smooth surface. The degree of pilling effect of cashmere knitted fabric has required the attention of consumers, manufacturers and researchers. Li et al. [19] found that the relationship between the pilling degree of cashmere knitted fabric and yarn properties was obtained using optimal scaling regression analysis. For the same spinning method, the dye color of cashmere fiber is of primary importance by influencing fabric pilling rates, due by the interaction of the actual yarn twisting and its CV and the yarn tensile strength.

Moreover, Liu and Wang [20] compared the cashmere yarn structure of ring, mule and rotor spinning by means of SEM observations. They showed that the structure of cashmere mule yarn was compacted and the hairiness of cashmere mule yarn was low than that of cashmere ring yarn and rotor yarn.

\section{Method and apparatus}

In order to establish which of the yarns are most appropriate for knitting garments regarding the pilling performance were realized tests according to the standard EN ISO 12945-2:2000 Textiles - Determination of Fabric Propensity to Surface Fuzzing and to Pilling - Part 2: Modified Martindale method [13, 23].

The tests were performed with the Nu-Martindale - abrasion and pilling tester, model 864. Were prepared $150 \mathrm{~mm}$ diameter specimens of the cloth to be tested. A circular sample, mounted in a specimen holder and subjected to a specific load, is rubbed in the face of an abrasive standard fabric in a translational movement tracing a Lissajous figure, also the specimen holder is additionally freely rotatable around its own axis, perpendicular on the plane of the specimen. [24]. 
One type of the evaluation for the pilling appearance of the knitted fabric is determined from the inspection interval to degradation of the sample. In according to the standard mentioned above, the samples were inspected every 2000 cycles with a magnifying glass and compared with standard photographic samples to establish the degree of degradation [2]. The other type of evaluation is the calculation of the weight loss percent of the fabrics, after 4000 rubs.

\section{Samples}

Like samples were used knitted fabric panels, catted from garments, obtained on a flat knitting machine Cotton with different gauge (table 1), using carded yarns from fibers like cotton, wool or mixed one e.g. Wool $40 \%+$ viscose $30 \%+$ polyamide $20 \%+$ Cashmere $10 \%$, wool $70 \%$ + nylon $30 \%$. Whole samples were conditioned [14].

Knits geometry are shown in the figure 2 and their characteristic are described in the table 1 .

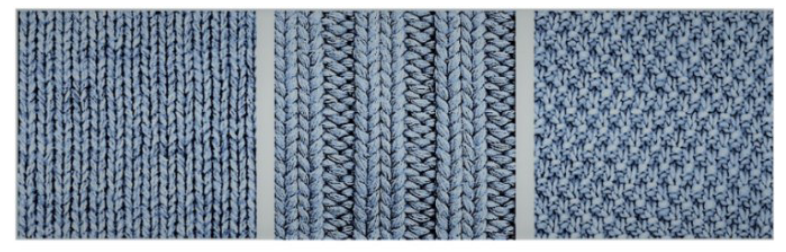

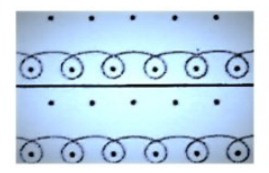

a.

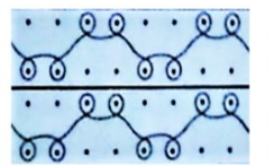

b.

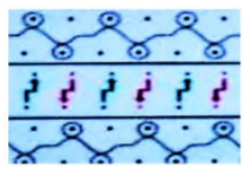

c.

Fig. 2. Knits geometry: $\mathrm{a}-$ single jersey, $\mathrm{b}-2 \times 2 \mathrm{rib}, \mathrm{c}-$ moss stitch.

Table 1. Knitted fabric characteristic.

\begin{tabular}{|c|c|c|c|c|c|c|c|}
\hline \multirow[b]{2}{*}{ Code } & \multirow[b]{2}{*}{$\begin{array}{l}\text { Fabric } \\
\text { geometry }\end{array}$} & \multirow[b]{2}{*}{$\begin{array}{c}\text { Raw } \\
\text { material }\end{array}$} & \multirow[b]{2}{*}{$\begin{array}{c}\text { Yarn } \\
\text { fineness } \\
{[\mathbf{N m}]}\end{array}$} & \multirow{2}{*}{$\begin{array}{c}\text { No. } \\
\text { of } \\
\text { ply } \\
\text { yarn }\end{array}$} & \multicolumn{2}{|c|}{ Fabric Density } & \multirow[b]{2}{*}{$\begin{array}{c}\text { Machine } \\
\text { gauge }\end{array}$} \\
\hline & & & & & $\begin{array}{l}\text { Wales } \\
\text { /50mm }\end{array}$ & $\begin{array}{l}\text { Rows } \\
\text { /50mm }\end{array}$ & \\
\hline S1 & $\begin{array}{l}\text { Single } \\
\text { jersey }\end{array}$ & Cotton & $70 / 2$ & 2 & 43 & 50 & $12 \mathrm{gg}$ \\
\hline S2 & $\begin{array}{l}\text { Single } \\
\text { jersey }\end{array}$ & Cotton & $50 / 2$ & 2 & 33 & 45 & $21 \mathrm{gg}$ \\
\hline S3 & $\begin{array}{l}\text { Single } \\
\text { jersey }\end{array}$ & Cotton & $50 / 2$ & 3 & 28 & 35 & $15 \mathrm{gg}$ \\
\hline S4 & $\begin{array}{l}\text { Single } \\
\text { jersey }\end{array}$ & Wool & $30 / 2$ & 1 & 38 & 45 & $12 \mathrm{gg}$ \\
\hline S5 & $\begin{array}{l}\text { Single } \\
\text { jersey }\end{array}$ & $\begin{array}{l}\text { Wool 70\%+ } \\
\text { Nylon 30\% }\end{array}$ & $15 / 2$ & 1 & 25 & 35 & $7 \mathrm{gg}$ \\
\hline S6 & Rib $4 \times 2$ & $\begin{array}{l}\text { Wool } 40 \%+ \\
\text { Viscose } 30 \%+ \\
\text { Polyamide } 20 \%+ \\
\text { Cashmere } 10 \%\end{array}$ & $15 / 1$ & 2 & 38 & 45 & $12 \mathrm{gg}$ \\
\hline S7 & $\begin{array}{l}\text { Moss } \\
\text { Stitch }\end{array}$ & Cotton & $70 / 2$ & 2 & 33 & 30 & $12 \mathrm{gg}$ \\
\hline
\end{tabular}


Cotton knitted fabric is breathable and transmits moisture, liquid and vapor, far away from the body and is absorbent and removes liquid from the skin, like a towel, according to Cotton Incorporated [26].

Cotton as a natural cellulose fiber, has a lot of characteristics such as: comfortable, soft hand, good absorbency, color retention, prints well, machine-washable, dry-cleanable, good strength, drapes well, easy to handle and sew [21].

Wool fiber is composed of protein substance called as keratin. The wool fibers have crimps or curls, which create air pockets and give the wool a spongy feel and create insulation for the wearer.

The characteristics of wool fiber are as follows: excellent absorbency, moisture regain is good, tend to be warmer than others, have poor resistance to alkalis but good resistance to acids, have good elasticity and resiliency [22].

\section{Assessment}

An objective evaluation of the pilling tendency of woven cloth and knitted fabric is a broad requirement of the textile industry [25].

To evaluate the pilling tendency in accordance with SN EN ISO 12945-2 a photo standard can be used, see figure 3 . Each photo standard consists of a series of 4 comparable photographs. Each comparable photograph shows the boundary between 2 marks (mark 4$5,3-4,2-3,1-2)$.

The surface condition of each test sample is judged against a photo standard, it can then be decided if the test sample is better, equal, or worse than the photo standard, resulting in a pilling mark [25].
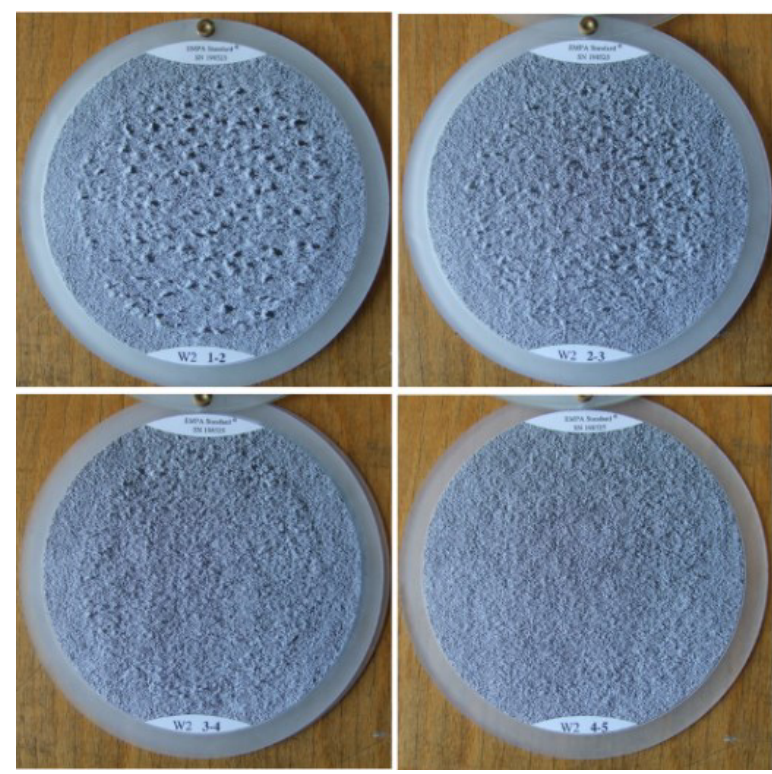

Fig. 3. Marking system [25]. Mark $5=$ no or very little pilling, Mark $4=$ light pilling formation, Mark 3 = moderate pilling formation, Mark 2 = distinct pilling formation, Mark $1=$ strong pilling formation, (Half marks are allowed). 


\section{Results}

In the table 2 are presented the samples appearance after 2000 and 4000 rubs and the table 3 show the values of mass loss percent obtained for all knitted fabric geometry and raw material from this study.

Table 2. Sample appearance after 2000 and 4000 rubs.

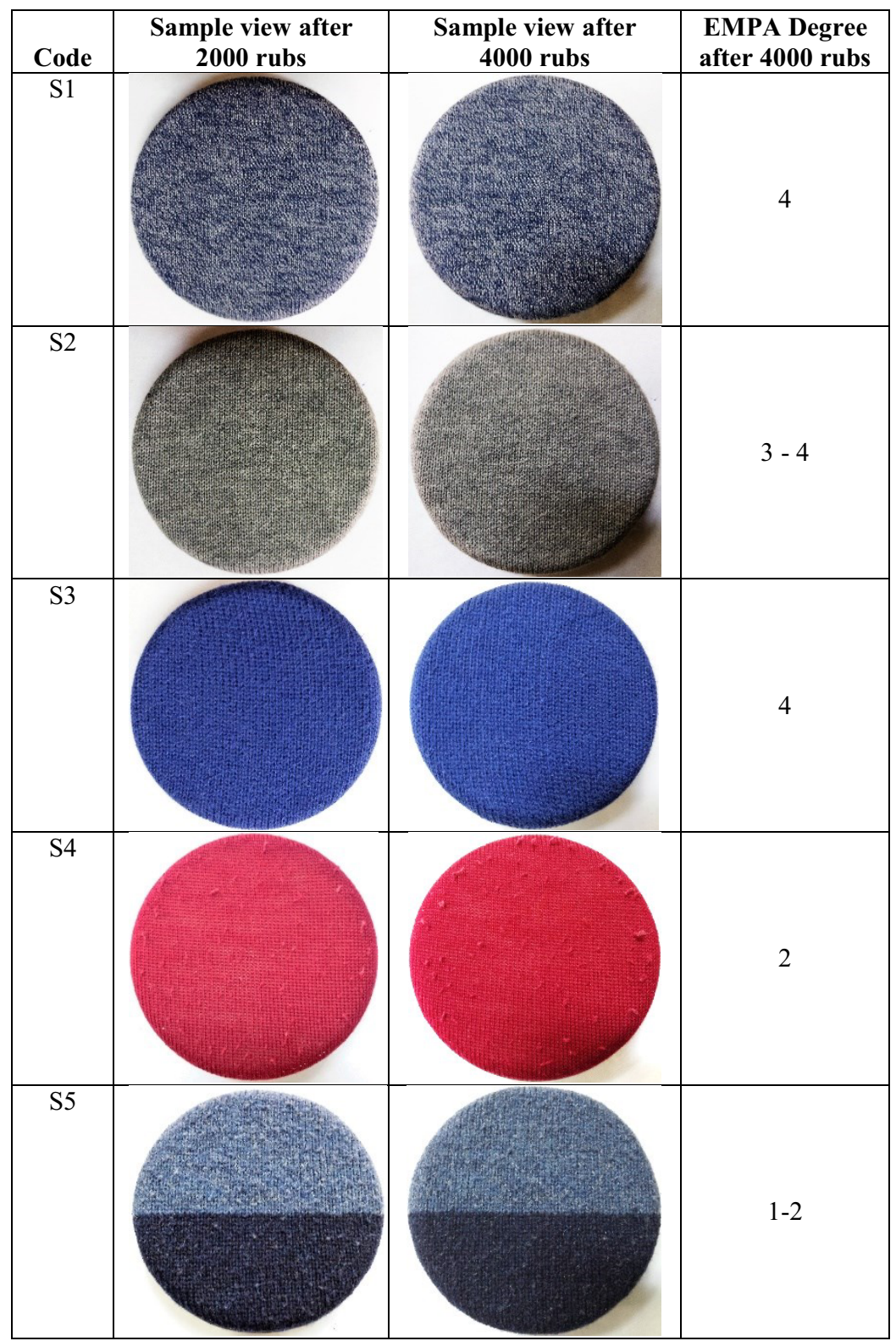




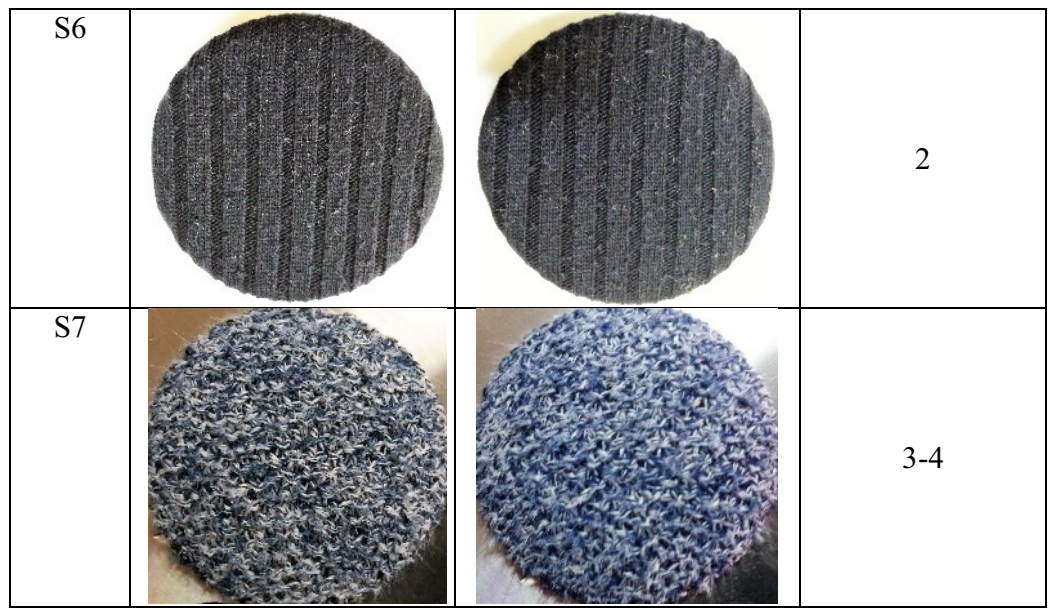

Table 3. The percent of mass loss.

\begin{tabular}{|l|l|l|l|l|l|}
\hline Code & $\begin{array}{c}\text { Knitted } \\
\text { fabric } \\
\text { geometry }\end{array}$ & Raw material & $\begin{array}{c}\text { Initial } \\
\text { Weight } \\
\text { [g] }\end{array}$ & $\begin{array}{c}\text { Final } \\
\text { Weight } \\
\text { [g] }\end{array}$ & $\begin{array}{c}\text { Loose } \\
\text { Weight } \\
{[\%]}\end{array}$ \\
\hline S1 & $\begin{array}{l}\text { Single } \\
\text { jersey }\end{array}$ & Cotton & 3.928 & 3.911 & 0.43 \\
\hline S2 & $\begin{array}{l}\text { Single } \\
\text { jersey }\end{array}$ & Cotton & 4.583 & 4.555 & 0.61 \\
\hline S3 & $\begin{array}{l}\text { Single } \\
\text { jersey }\end{array}$ & Cotton & 5.921 & 5.910 & 0.19 \\
\hline S4 & $\begin{array}{l}\text { Single } \\
\text { jersey }\end{array}$ & Wool & 4.236 & 4.172 & 1.51 \\
\hline S5 & $\begin{array}{l}\text { Single } \\
\text { jersey }\end{array}$ & $\begin{array}{l}\text { Wool } 70 \%+\text { Nylon } \\
30 \%\end{array}$ & 6.505 & 6.452 & 0.81 \\
\hline S6 & $\begin{array}{l}\text { Wool 40\%+ } \\
\text { Riscose } 30 \%+ \\
\text { Polyamide } 20 \%+\end{array}$ & 9.501 & 9.450 & 0.54 \\
\hline Cashmere $10 \%$
\end{tabular}

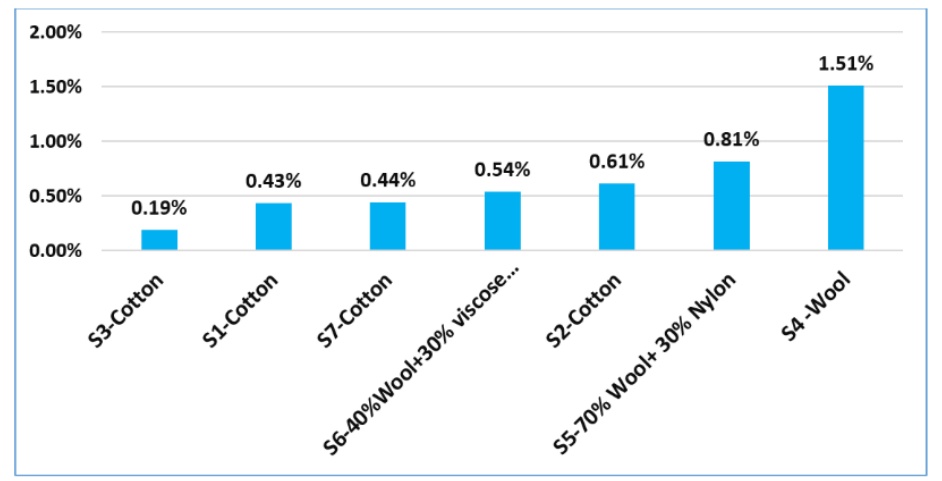

Fig. 4. Histogram of weight loss, according to the raw material and fabric geometry. 


\section{Discussions and conclusions}

In this study, the pilling tendency on a textile's surface for three type of weft knitted fabric geometry - single jersey, $2 \times 2$ rib and moss stitch - produced from ring yarns and raw material like cotton, wool and mixed yarns were evaluated. According to the raw material, percent of mass loss is higher for knitted samples from wool yarn than cotton samples.

If we increase the yarn fineness (S5 and S6), the mass loss will increase, see figure 4 and table 3 .

For the same raw material (cotton $70 / 2 \mathrm{Nm}$ ), but different geometry (S7 and S1), percent of mass loss is higher in the case of S7.

For the same raw and pattern (S2 and S3) if we add one more ply yarn (e.g. S3) mass loss percent decrease by $68,85 \%$, see figure 4 and table 3 .

Concerning the influence of fabric geometry on the pilling tendency:

- If we analyze the appearance of the sample surface after 4000 rubs can observe that, single jersey has a good resistance than rib and moss stitch structure, table 3 show.

- It can be said that the knit geometry and raw material have an effect on the pilling performance of knit fabrics. To be able to produce knitted fabrics for garments whose abrasion resistance and pilling performance are high, compact yarns should be used.

- Try to avoid fabrics that are made from fiber blends. Knitted or woven fabrics that combine different types of threads - especially those that combine natural and synthetic fibers - are more likely to pilling degradation.

- We can choose woven fabrics than knits. Woven fabrics goes to pilling, less than knits. Of course we love our knits, so choose one that is tightly knit over a looser knit.

- For clothes that you suspect will pill, use the washer's gentle cycle. The slower agitation and shorter wash cycle will protect your clothes. Or, choose hand washing which is even more gentle.

\section{References}

1. http://internet.ktu.lt/lt/mokslas/zurnalai/medz/pdf/medz0-106/15\%20Textile...(pp.297-301).pdf

2. I. Gykytė, E. Strazdienè, R. Titas, V. Urbelis, Pilling of Knitted Materials Science, Medžiagotyra 8, $316(2002)$

3. https://www.researchgate.net/publication/267772861_The_Influence_of_Structure_Parameters of_Weft_Knitted_Fabrics_on_Propensity_to_Pilling

4. C. Candan, L. Önal, Textile Research Journal, 72, 164 (2002)

5. https://www.researchgate.net/publication/228544267_Structure_Properties_of_Knits_from_Natu ral_Yarns_and_their_Combination_with_Elastane_and_Polyamide_Threads

6. N. Emirhanova, Y. Kavusturan, Fibers \& Textiles in Eastern Europe, 16, 69 (2008)

7. N. Uçar, S. Ertuğrul, Prediction of Fuzz Fibers on Fabric by Using Neural Network and Regression Analysis Fibers \& Textiles in Eastern Europe, 2, 58 (2007)

8. F. Ceken, Pilling of Flat Knitted Fabrics Knitting Technology, 2, 16 (2000)

9. M. Akaydin, Y. Can, Fibres \& Textiles in Eastern Europe, 18, 51 (2010)

10. http://www.fibtex.lodz.pl/article166.html

11. N. Çelik, Z. Değirmenci, H.K. Kaynak, Tekstil ve Konfeksiyon, 1, 41 (2010)

12. http://internet.ktu.lt/lt/mokslas/zurnalai/medz/pdf/medz0-106/15\%20Textile...(pp.297-301).pdf

13. ISO 12945-2:2000 Textiles - Determination of Fabric Propensity to Surface Fuzzing and to Pilling - Part 2: Modified Martindale method

14. ISO 139:2005 Textiles - Standard Atmospheres for Conditioning and Testing.

15. Long Li, Meijing Zhu, Xiaojuan Wei, Fibres \& Textiles in Eastern Europe, 22, 1, 74 (2014)

16. http://www.fibtex.lodz.pl/50_11_39.pdf.

17. C. Candan, L. Önal. Textile Research Journal, 72, 164 (2002) 
18. https://researchbank.rmit.edu.au/view/rmit:5858

19. L. Li, G. Jia, W. Zhou, Fibers \& Textiles in Eastern Europe, 17, 76 (2009)

20. J. Liu, S. Wang, Shanghai Textile Science \& Technology, 26, 19 (1998)

21. http://www.swicofil.com/products/001 cotton.html, Access date: March 2017

22. http://textilelearner.blogspot.ro/2011/08/wool-fiber-properties-of-wool-fiber_5920.html, Access date: March 2017

23. A.M. Coldea, D. Vlad, C. Budulan, Annals of the Oradea University. Fascicle of TextileLeatherwork, June 1st-2nd, XIII, 63 (2012)

24. Technical book of Nu-Martindale - abrasion and pilling tester, model 864

25. http://www.testfabrics.com/download.php?id=uploadfiles $/ \mathrm{TmpJPQ}==$.pdf\& filename=Empa

26. https://www.thespruce.com/how-to-prevent-clothes-from-pilling-2146667. Access date: March 2017 